\title{
Tandonia kusceri (Pulmonata: Milacidae), a slug new for Slovakia
}

\author{
ONDŘEJ KorÁBeK ${ }^{1}$, TOMÁš Č́EJKA² \& LUCIE JUŘIČKOVÁ ${ }^{3}$ \\ ${ }^{1}$ Charles University in Prague, Faculty of Science, Department of Ecology, Viničná 7, CZ-12844 Praha 2, Czech Republic, \\ e-mail: ondrej.korabek@gmail.com (corresponding author) \\ ${ }^{2}$ Slovak Academy of Sciences, Institute of Botany, Dúbravská cesta 9, SK-845 23 Bratislava, Slovakia, e-mail: t.cejka@gmail.com \\ ${ }^{3}$ Charles University in Prague, Faculty of Science, Department of Zoology, Viničná 7, CZ-12844 Praha 2, Czech Republic, \\ e-mail: lucie.jurickova@seznam.cz
} KorÁBeK O., ČEJKA T. \& JUŘIČKovÁ L., 2016: Tandonia kusceri (Pulmonata: Milacidae), a slug new for Slovakia.
- Malacologica Bohemoslovaca, 15: 3-8. Online serial at <http://mollusca.sav.sk> 30-June-2016.

\begin{abstract}
Tandonia kusceri (Wagner, 1931) is reported from Slovakia for the first time. The slug was found in the Ružinov and Petržalka housing estates, Bratislava, in 2014 and 2015, respectively. Our observations suggest that the species is well established in the Slovak capital. This finding calls for verification of some of the older reports of a similar species Tandonia rustica beyond the eastern border of its native range. Owing to unresolved taxonomic issues, the name $T$. kusceri should be applied only tentatively.
\end{abstract}

Key words: Tandonia rustica, first record, urban fauna, non-native, introduction

\section{Introduction}

Until recently, only two species of the genus Tandonia Lessona \& Pollonera, 1882 had been reported from Slovakia: Tandonia budapestensis (Hazay, 1881) and Tandonia rustica (Millet, 1843). The former is a synanthropic species known so far from just a few records in the south of the country (HoRsÁK et al. 2015), a continuation of its scattered distribution in Hungary (PINTÉR \& SUARA 2004). Tandonia rustica has been reported from three grid squares in the southwest of Slovakia (LISICKÝ 1991). These localities are beyond the eastern limit of the more or less continuous range of the species, which extends as far east as the Czech Republic (eastern Bohemia) and Austria (Tirol and Upper Austria). The species is absent from Moravia in the south-east of the Czech Republic, leaving a gap between its range and the records from Slovakia and Hungary (Reischütz 1986, SEIdl 1998, HorsÁk et al. 2013). However, there are a few records attributed to T. rustica from western Austria (REISCHÜTz 1986).

In September 2014, we found, together with other participants of the annual meeting of the Czech and Slovak malacologists, slugs resembling T. rustica in Ružinov, Bratislava (Fig. 1). The slugs were aggregated among the foundations of a long demolished school gym within a housing area built in the 1960s (Fig. 2). At the very same spot a population of the non-native snail Helix lucorum had been discovered recently (ČEJKA \& ČAČANÝ 2014). Later, we found similar Tandonia slug also among preserved material collected in April 2015 in Petržalka housing estate, Bratislava. It was found there in a small deciduous forest patch (composed mainly by Acer platanoides and Fraxinus pennsylvanica trees; Fig. 3) by a railway. The housing estate, along with the railway and nearby roads, was built in the 1970-1980s; aerial photographs from the 1950s show an athletic stadium at the site. These two sites lie on the opposite banks of the Danube River and almost $5 \mathrm{~km}$ apart.

Tandonia rustica has been reported from Bratislava previously (PONEC 1972, LISICKÝ 1991); however, the anthropogenic habitat of the populations reported here is different from the usual habitat of the species at the eastern limits of its continuous range. In the Czech Republic, T. rustica mostly lives in broadleaf forests, often on scree slopes, and in stone accumulations, which is in agreement with the habitat description provided by WiKTOR (1987). Also, we have never observed such large aggregations of this species in natural sites (though this behaviour may differ in other parts of the species range; U. SCHNEPPAT, personal communication). For these reasons and because of a slightly different colouration, we suspected that we were dealing with a different, non-native Tandonia species, most likely with Tandonia kusceri (Wagner, 1931). We tested this assumption by comparison with the other Slovak Tandonia species and a non-native population of T. kusceri from USA, using dissections and a mitochondrial marker.

\section{Material and methods}

We analysed two specimens collected on September 28, 2014, in Ružinov housing estate (Table 1; Fig. 2); see also ČEJKA \& ČAČANÝ (2014) and one individual from the Petržalka housing estate. The individuals were fixed in ethanol, dissected and identified following WIKTOR (1987, 1996).

To further demonstrate that the slugs do not belong to any of the two Tandonia species reported from Slovakia before, we sequenced a fragment of the mitochondrial $16 \mathrm{~S}$ rRNA gene from these specimens and from representatives of both Tandonia species reported from Slovakia already, T. rustica and T. budapestensis (Table 1; samples from the Czech Republic were used). For a comparison, 


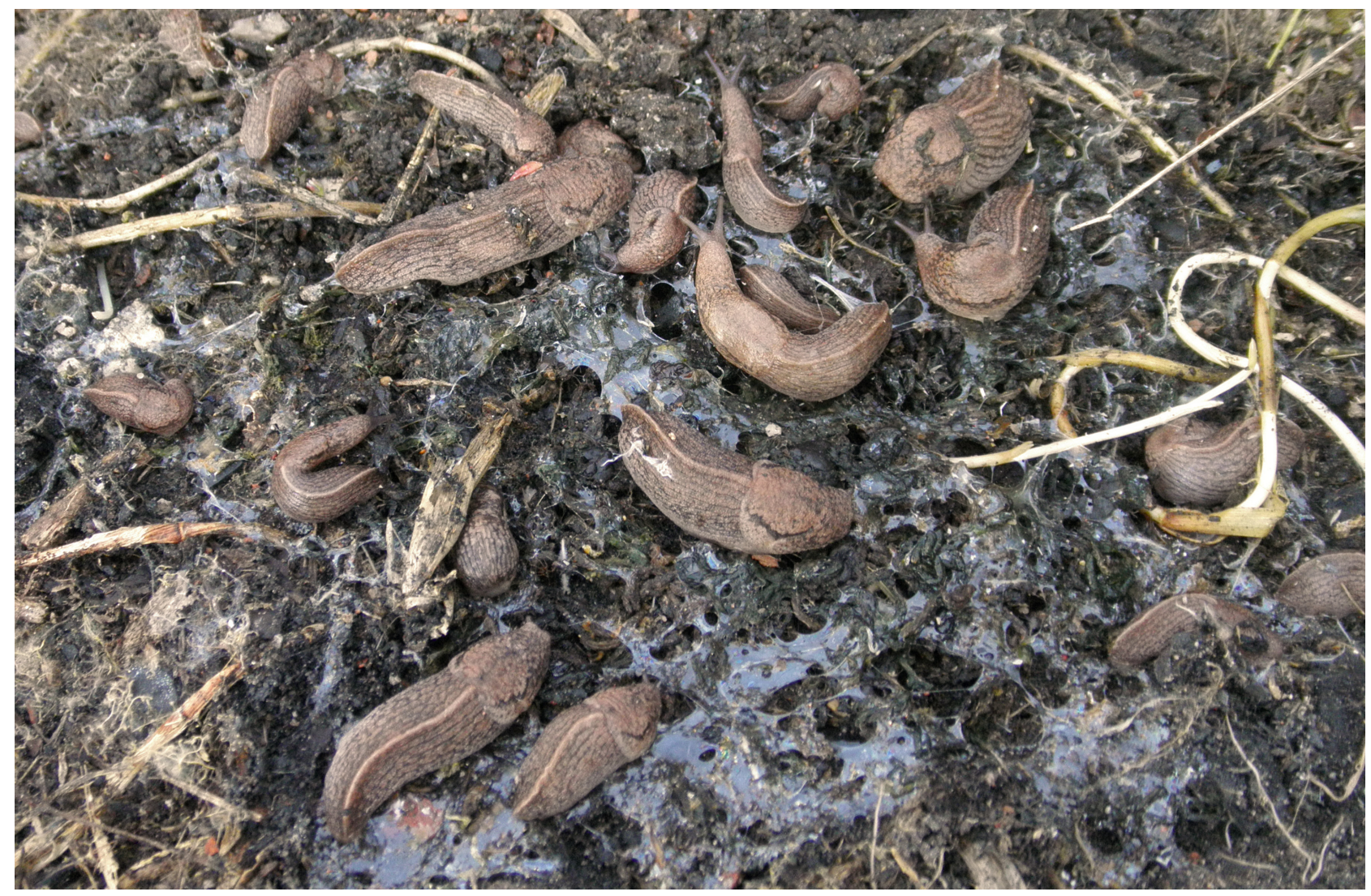

Fig. 1. Aggregation of Tandonia kusceri (Wagner, 1931) in Bratislava - Ružinov, 2014, September 28. Photo by M. Maňas.

we also analysed two specimens from another non-native T. kusceri population from the suburbs of Chicago, USA (GERBER 2014).

DNA extraction, amplification and sequencing followed the same methods as in KORÁBEK et al. (2016). The primer pair Scs1 and Scs2 (CHIBA 1999) was used for PCR amplification of a fragment of the 16S rRNA gene; from the improperly preserved individual form Petržalka we eventually obtained only a shorter fragment (433 bp at the 3 'end) using a primer pair by STEINKE et al. (2004). Unique sequences obtained were deposited in GenBank (Table 1). We have also attempted an analysis of the widely used fragment of the gene for cytochrome c oxidase subunit I, for which there are already sequences from Milacidae species available in GenBank (Rowson et al. 2014). Using the primer pair LCO1490 and HC02198 (FoLMER et al. 1994), we initially amplified and sequenced the COI fragment from $T$. rustica and one of the specimens of $T$. kusceri from Ružinov. However, these data (GenBank acc. nos. KU641256 and KU641257) were eventually not used any further (see below for explanation).

The 16S sequences were aligned using MAFFT 7 and the L-INS-i algorithm (КАTOH \& STANDLEY 2013), and from the alignment pairwise uncorrected genetic distances were calculated after deletion of all columns with gaps or missing data (Table 2).

\section{Results and discussion}

Whereas $T$. rustica is usually light brown or pinkish, with a dark pigmentation on the body posterior to the mantle aggregated into distinct spots, the dark pattern of the specimens from Bratislava was much more diffuse (Fig. 1), as it is usual for T. kusceri (WIKTOR 1996). The length of the epiphallus and vas deferens relative to the penis, the shape of the transition between them and the shape of the penial

Table 1. Sampling localities and GenBank accession numbers. Vouchers of T. rustica and T. kusceri from Bratislava are deposited in the private collection of O. Korábek, specimens from USA are deposited in the Field Museum of Natural History, Chicago, USA, \#328572.1 and \#328572.4. Where the obtained sequences were identical, only one representative has been submitted to GenBank; for details refer to the Materials and Methods section.

\begin{tabular}{|c|c|c|c|}
\hline species & locality & GPS coordinates & GenBank accession numbers \\
\hline T. kusceri & Slovakia: Bratislava, Ružinov, Borodáčova Street & $48.1536^{\circ} \mathrm{N}, 17.1726^{\circ} \mathrm{E}$ & \multirow{2}{*}{$\begin{array}{l}\text { KU234273 (16S), } \\
\text { KU641257 (COI) }\end{array}$} \\
\hline T. kusceri & $\begin{array}{l}\text { Slovakia: Bratislava, Petržalka, Černyševského } \\
\text { Street }\end{array}$ & $48.1302^{\circ} \mathrm{N}, 17.1186^{\circ} \mathrm{E}$ & \\
\hline T. kusceri & $\begin{array}{l}\text { USA: Illinois: suburbs of Chicago, Cook County, } \\
\text { Brookfield, Jefferson Avenue }\end{array}$ & $41.8283^{\circ} \mathrm{N},-87.8564^{\circ} \mathrm{E}$ & KU234274 (16S) \\
\hline T. rustica & Czech Republic: Roztoky, U Eremita & $50.0154^{\circ} \mathrm{N}, 13.8589^{\circ} \mathrm{E}$ & $\begin{array}{l}\text { KU234275 (16S), } \\
\text { KU641256 (COI) }\end{array}$ \\
\hline T. budapestensis & Czech Republic: Čáslav, Generála Moravce Street & $49.9127^{\circ} \mathrm{N}, 15.3882^{\circ} \mathrm{E}$ & KU234276 (16S) \\
\hline
\end{tabular}




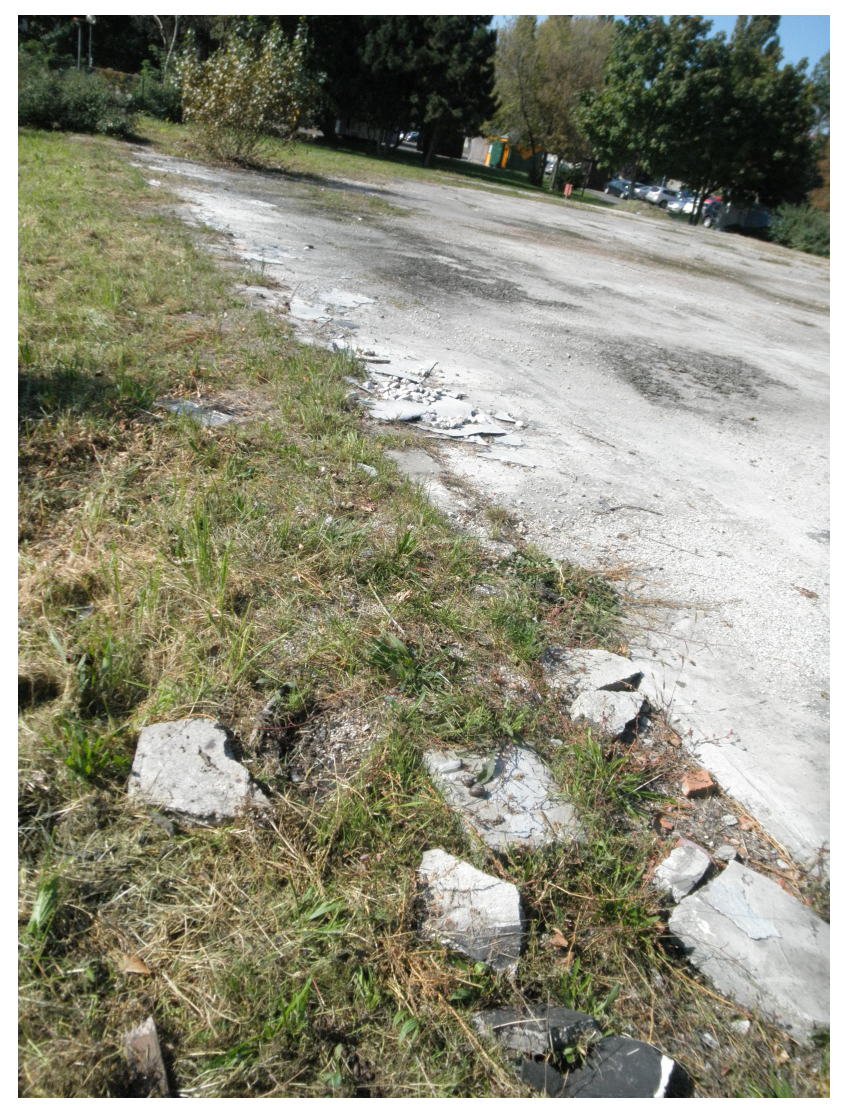

Fig. 2. The locality of T. kusceri in Bratislava - Ružinov; September 2014. The slugs were found under bricks and pieces of concrete. Photo by M. Maňas.

papilla conformed to the description of T. kusceri provided by WiкTOR (1996) (Figs. 4, 5). The bursa copulatrix was not pointed and the epiphallus was coiled, as it should be in $T$. kusceri.

The 16S sequences obtained from the Slovak samples were identical. The T. kusceri from Chicago, Illinois, USA, differed from Slovak samples in only three positions, while the $T$. rustica sample differed by $17 \%$ from all $T$. kusceri samples (Table 2). Although high, this value is still within the range occasionally observed within slug species (PINCEEL et al. 2005).

In the COI locus T. kusceri sample from Ružinov differed from T. rustica (our sample and GenBank acc. no. KF894265; Rowson et al. 2014) by $14 \%$. However, the COI sequences from T. kusceri and T. rustica were highly divergent from the available sequences of other Milacidae species (Milax gagates, Tandonia sowerbyi, and T. budapestensis; Rowson et al. 2014). Unlike for the other Milacidae, BLAST searches against the GenBank nucleotide database (performed May 2, 2016) resulted in best hits outside Milacidae (within Vertiginidae) for T. kusceri and $T$. rustica. One may wonder whether one of these two

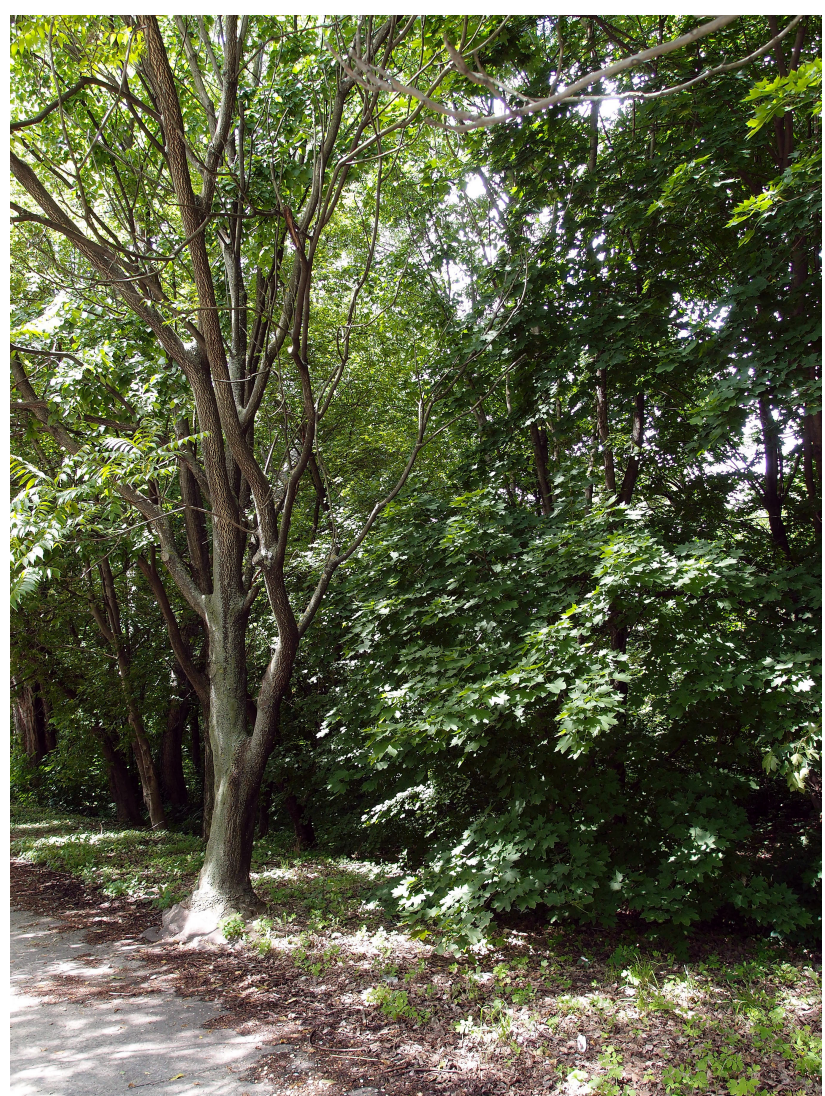

Fig. 3. The locality of T. kusceri in Bratislava - Petržalka; June 2016. Photo by T. Čejka

groups of milacid COI sequences represents pseudogene sequences or, probably more likely, they just reflect a deep divergence in mitochondrial genes within Milacidae and possibly non-monophyly of Tandonia in respect of Milax. There were no stop codons in our sequences or in the data from Rowson et al. (2014) either; translated to amino acid sequences, T. rustica and T. kusceri differ from the other Milacidae in a few chemically dissimilar amino acids (e.g. threonine vs. lysine), but these amino acids can be found at homologous positions in some other European slug families. Due to the lack of 16S data from other Milacidae and related families we could not have tested the alternative explanations, but we decided not to use COI further just to be sure.

Based on the internal morphology, the habitat and the molecular data we conclude that the population from Bratislava belongs not to T. rustica, but to T. kusceri. This is the first record of T. kusceri in Central Europe. The species has been described from the environs of Niš, Serbia, and its reported range includes Dobrogea in Romania, Bulgaria, European Turkey, Serbia, Macedonia, Montenegro, and Croatia (Wiktor 1987, 1996, WikTor \& JURKovsKa 2007,

Table 2. Uncorrected genetic distances (p-distances) between the 16S fragments of the analysed samples.

\begin{tabular}{|l|l|l|l|l|}
\hline & T. kusceri $(\mathrm{SK})$ & T. kusceri $(\mathrm{US})$ & T. rustica $(\mathrm{CZ})$ & T. budapestensis $(\mathrm{CZ})$ \\
\hline T. kusceri $(\mathrm{SK})$ & - & & & \\
\hline T. kusceri $(\mathrm{US})$ & 0 & - & & \\
\hline T. rustica $(\mathrm{CZ})$ & 0.17 & 0.17 & - & \\
\hline T. budapestensis $(\mathrm{CZ})$ & 0.20 & 0.20 & 0.22 & - \\
\hline
\end{tabular}




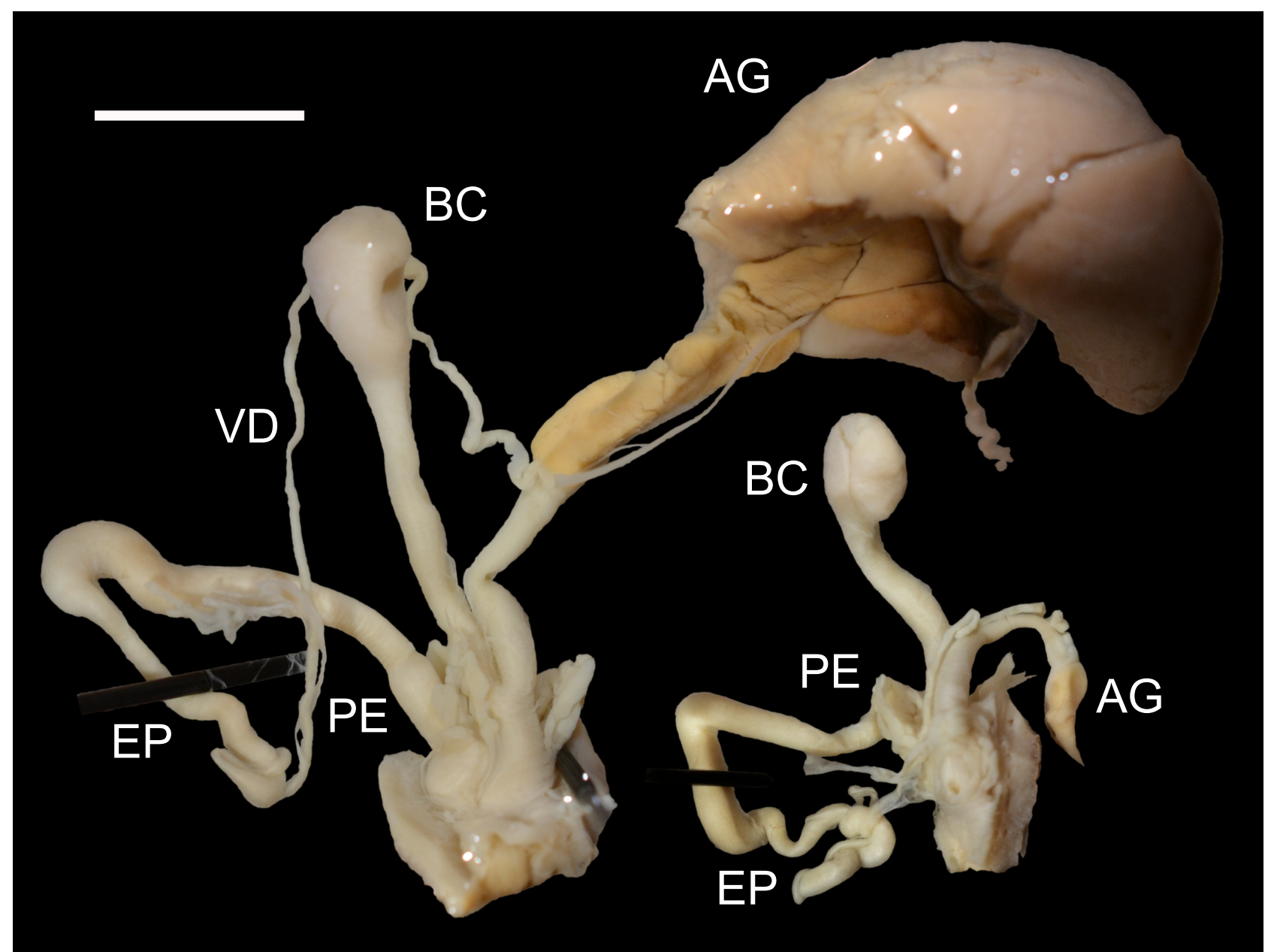

Fig. 4. The genital systems of $T$. kusceri individuals from Bratislava - Ružinov; scale bar $5 \mathrm{~mm}$. AG - albumen gland; BC - bursa copulatrix; EP - epiphallus; PE - penis. Photo by O. Korábek.

TelebaK et al. 2013). Tandonia kusceri often lives synanthropically and is commonly found in habitats similar to the sites in Bratislava (WIKTOR 1987). Isolated populations of $T$. kusceri have been reported from the Ukraine (SoN 2004, LeONov 2007), Moldova (BALAshov et al. 2013) and the USA (Gerber 2014).

Presence of individuals of different sizes at the Ružinov site in 2014 (Fig. 1) already indicated that the T. kusceri population was successfully reproducing. In June 2016 Tomáš Čejka counted there 83 individuals within half an hour, proving that the population successfully overwinters and reproduces. Population at Petržalka site was less numerous, only seven individuals were found during the half an hour of individual searching. Although we have not found any other T. kusceri populations in an immediate vicinity of the Ružinov site, the second record from a rather distant site in Petržalka suggests that the species may be already well established in the Slovak capital. Slugs identified then as T. rustica had been found in Slovakia for the first time between 1965 and 1967 in vineyards in the northern suburbs of Bratislava (PONEC 1972). LISICKÝ (1991) added a further record from Bratislava and another one from the Czech-Slovak border near Skalica or Holíč Only PONEC (1972) figured a specimen from the reported locality, and the coloration differed from the slugs reported here by having rather distinct dark spots, as is usual in T. rustica, but a reliable identification would be possible only based on characters on genitalia. No voucher specimens of "T. rustica" are preserved in the collections of M. Lisický (Bratislava), and we are not aware of any extant vouchers from Ponec's research. It is possible that at least some of these records actually refer to T. kusceri, which presence in Slovakia may thus already last several decades.

There might be some more non-native occurrences of T. kusceri in the literature hidden behind the name T. rustica from adjacent countries. PINTÉR \& SUARA (2004) listed two occurrences of T. rustica in Hungary, in the urban area of Esztergom (north of the country) and at an unspecified site in the Köszeg County (northwestern Hungary). ReIsСнÜтZ (1986) reported T. rustica from Burgenland (eastern Austria, actually near Köszeg) and from Vienna and its vicinity. We suggest that the species identity of these T. rustica populations beyond its range limits should be revised, especially when they originate from urban habitats.

However, the name T. kusceri for the non-native Slovak slugs should be used with caution. The genus has the centre of diversity in the Balkans, and taxonomy of the species living there is far from resolved. WIKTOR (1987) suggested that Tandonia serbica (Wagner, 1930), described from the same type locality as T. kusceri, might represent just a different stage of development or genital morph of the latter. If synonymous, the name $T$. serbica would have priority. 
The presented finding is just another one in a row of south-European species discovered in the capitals of the region (e.g. Pintér \& SuAra 2004, Fischer et al. 2008, Peltanová et al. 2012, Duda \& Mrkvicka 2014). Large cities are transport hubs and centres of trade and the new alien gastropod species have been most likely introduced as contaminants with goods. Thus the concentration of new records in the capitals may be real and not only an artefact of better sampling. Nevertheless, as long as the introduced species remain restricted to the urban habitats, their significance for the regional biota is limited. Milacid slugs seem to be able to colonize new territories quite successfully. Some other species of the family (Milax gagates, Tandonia sowerbyi, T. budapestensis and others; e.g. ReISE et al. 2006; Welter-Schultes 2012; Hutchinson \& Reise 2013; Rowson et al. 2014) already have considerable secondary ranges and some are pests. Only time will tell whether T. kusceri will be able to spread across Central Europe.

\section{Ackowledgements}

We thank Jochen Gerber (Field Museum of Natural History, Chicago) for samples of T. kusceri from the USA, Michal Maňas for photos, and Juraj Čačaný for help with the historic Slovak records. Adam Petrusek and Heike Reise provided valuable comments on an earlier version of the manuscript. The work was supported by the Grant Agency of the Charles University in Prague (GAUK project no. 615).

\section{References}

Balashov I. A., Son M. O., Coadă V. \& Welter-Schultes F., 2013: An updated annotated checklist of the molluscs of the Republic of Moldova. - Folia Malacologica, 21: 175-181.

ČEJKA T. \& ČAČANÝ J., 2014: The first record of the Turkish snail (Helix lucorum L., 1758) in the Slovak Republic. - Malacologica Bohemoslovaca, 13: 124-125.

ChiBA S., 1999: Accelerated evolution of land snails Mandarina in the oceanic Bonin Islands: evidence from mitochondrial DNA sequences. - Evolution, 53: 460-471.

Duda M. \& Mrkvicka A., 2014: Zur Ausbreitung der Neozoen Monacha cantiana (MONTAGU 1803), Hygromia cinctella (DRAPARNAUD 1801), Cepaea nemoralis (LINNÉ 1758) und Cornu aspersum (O. F. MÜLLER 1774) im südwestlichen Umland von Wien. - Nachrichtenblatt der Ersten Vorarlberger Malakologischen Gesellschaft, 21: 11-13.

Fischer W., NovaK J. \& Reinelt K., 2008: Beiträge zur Kenntnis der österreichischen Molluskenfaua XIII. Zum Vorkommen von Helix lucorum LINNE 1758, Cernuella neglecta (DRAPARNAUD 1805) und Cernuella virgata (DA COSTA 1758) in Wien (Gastropoda: Mollusca). - Nachrichtenblatt der Ersten Vorarlberger Malakologischen Gesellschaft, 15: 63-64.

Folmer O., Black M., Hoeh W., Lutz R. \& Vrijenhoek R., 1994: DNA primers for amplification of mitochondrial cytochrome c oxidase subunit I from diverse metazoan invertebrates. - Molecular Marine Biology and Biotechnology, 3: 294-299.

Gerber J., 2014: First American record of the exotic slug Tandonia kusceri (Gastropoda: Milacidae). - The Nautilus, 128: 59-63.

Horsák M., JuŘIČKovÁ L. \& PICKA J., 2013: Měkkýši České a Slovenské republiky. Molluscs of the Czech and Slovak Republics. - Nakladatelství Kabourek, Zlín, 264 pp.

Horsák M., ČejKa T., JuřičKová L., Beran L., HoráČKová J., Hlaváč J. Č., DvoŘák L., Hájek O., Mañas M. \& Ložek V.,

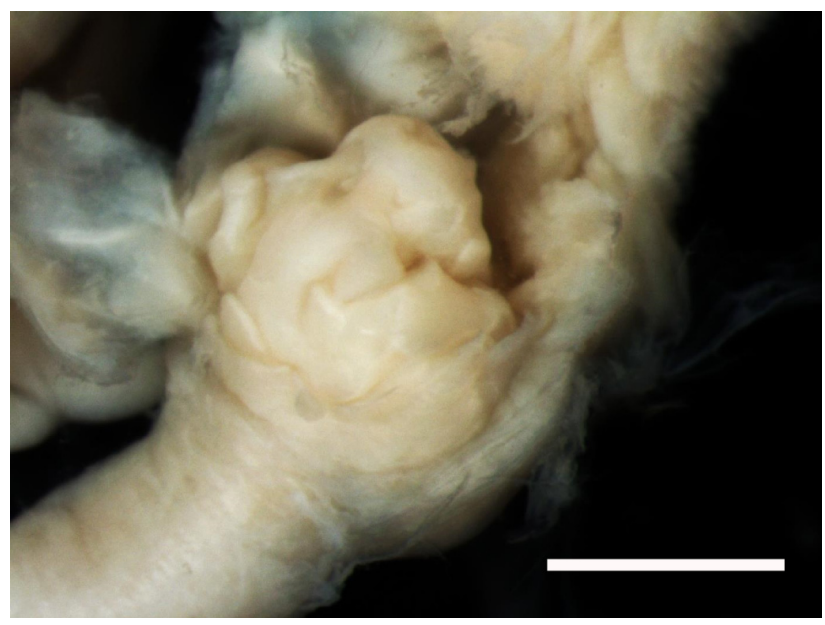

Fig. 5. Penial papilla of T. kusceri from Bratislava - Ružinov; scale bar $1 \mathrm{~mm}$. Photo by O. Korábek.

2015: Check-list and distribution maps of the molluscs of the Czech and Slovak Republics. - Online at http://mollusca.sav. sk/malacology/checklist.htm, accessed November 25, 2015.

Katoh K. \& Standley D. M., 2013: MAFFT multiple sequence alignment software version 7: improvements in performance and usability. - Molecular Biology and Evolution, 30: 772780.

KorÁbeK O., JuŘičKová L. \& Petrusek A., 2016: Splitting the Roman snail Helix pomatia Linnaeus, 1758 (Stylommatophora: Helicidae) into two: redescription of the forgotten Helix thessalica Boettger, 1886. - Journal of Molluscan Studies, 82: $11-22$.

Leonov S. V., 2007: The first record of the Tandonia kusceri (Pulmonata, Milacidae) in Crimea and a few remarks about its natural habitats. - Vestnik Zoologii, 41(2): 142.

LISICKÝ M. J., 1991: Mollusca Slovenska. [Mollusca of Slovakia]. - Veda, Bratislava, 344 pp.

Peltanová A., Petrusek A., Kment P. \& JuŘičková L., 2012: A fast snail's pace: colonization of Central Europe by Mediterranean gastropods. - Biological Invasions, 14: 759-764.

Pinceel J., Jordaens K. \& Backeljau T., 2005: Extreme mtDNA divergences in a terrestrial slug (Gastropoda, Pulmonata, Arionidae): accelerated evolution, allopatric divergence and secondary contact. - Journal of Evolutionary Biology, 18: 1264-1280.

PINTÉR L. \& SuARa R., 2004: Magyarországi puhatestüek katalógusa hazai malakológusok gyüjtései alapján. [Catalogue of the Hungarian molluscs based on the collectings of Hungarian malacologists]. - Magyar Természettudományi Múzeum, Budapest, 574 pp.

PoneC J., 1972: Mollusca Malých Karpát. [Mollusca of the Malé Karpaty Mts.]. - Acta Rerum Naturalium Musei Nationalis Slovaci, 18: 71-114.

ReISchÜTZ P. L., 1986: Die Verbreitung der Nacktschnecken Österreichs (Arionidae, Milacidae, Limacidae, Agriolimacidae, Boettgerillidae). - Sitzungsberichte der Akademie der Wissenschaften, mathematisch-naturwissenschaftliche Klasse, 195: 67-190.

Reise H., Hutchinson J. M. C. \& Robinson D. G., 2006: Two introduced pest slugs: Tandonia budapestensis new to the Americas, and Deroceras panormitanum new to the eastern USA. - The Veliger, 48: 110-115.

Rowson B., Anderson R., Turner J. A. \& Symondson W. O., 2014: The slugs of Britain and Ireland: undetected and undescribed species increase a well-studied, economically important fauna by more than 20\%. - PLoS ONE, 9: e91907.

SEIDL F., 1998: Vorkommen von Cochlostoma s. septemspirale 
(RAZOUMOWSKY 1789) und Tandonia rustica (MILLET 1843 ) in der Umgebung von Braunau am lnn, Oberösterreich. - Mitteilungen der Zoologischen Gesellschaft Braunau, 7(2): $125-131$.

Son M. O., 2004: New record of Tandonia kusceri (Pulmonata, Milacidae) in Ukraine - Vestnik Zoologii, 38: 76.

Steinke D., Albrecht C. \& Pfenninger M., 2004: Molecular phylogeny and character evolution in the Western Palaearctic Helicidae s.l. (Gastropoda: Stylommatophora). - Molecular Phylogenetics and Evolution, 32: 724-734.

Telebak B., Brajković M. \& ĆurČić S., 2013: Contribution to the knowledge of the slugs (Gastropoda: Stylommatophora: Limacidae and Milacidea) from Montenegro. - Bulletin of the
Natural History Museum in Belgrade, 6: 55-64.

Welter-Schultes F., 2012: European non-marine molluscs, a guide for species identification. - Planet Poster Editions, Göttingen, $679 \mathrm{pp}$

WikTor A., 1987: Milacidae (Gastropoda, Pulmonata) - systematic monograph. - Annales Zoologici, 41: 153-319.

WikToR A., 1996: The slugs of the former Yugoslavia (Gastropoda terrestrial nuda - Arionidae, Milacidae, Limacidae, Agriolimacidae). - Annales Zoologici, 46: 1-110.

WIKTOR A. \& JURKOWSKA J., 2007: The collection of terrestrial slugs (Gastropoda: Pulmonata) at the Museum of Natural History, Wrocław University (Poland). - Folia Malacologica, 15: 83-93. 